\title{
The ending of Hebrews reconsidered
}

\author{
Gert J. Steyn \\ (Department of New Testament Studies, University of Pretoria, Private Bag X20, Hatfield, Pretoria 0028, South Africa; \\ Email: Gert.Steyn@up.ac.za)
}

\section{Problem statement and hypothesis}

Opinions regarding the ending of Hebrews differ widely amongst scholars. Most scholars these days are of the opinion that the whole of Hebrews 13 is authentic and that it belongs to the rest of the book. ${ }^{1}$ Others, however, have noticed a possible supplement (postscript ${ }^{2}$ ) at the end of Hebrews - despite the fact that there is no supporting external evidence from our existing pool of manuscripts. The internal evidence regarding differences in tone, character, and more specifically the format of an early Christian letter ending at the end of the document, enhanced this suspicion. It seems odd that Hebrews does not present itself as a letter and completely lacks a letter opening (prescript), ${ }^{3}$ yet it contains, what seems to be, a letter closure. This odd situation could either be the result of a lost letter opening, or an added letter ending. It seems easier to argue in favour of a possible addition of the letter ending, rather than to suggest that a potential letter opening got lost during the course of history. Although not impossible, it would be rather difficult to explain why such a letter opening got lost, especially in light of the fact that letter openings usually contain more important information about the author and the addressees, than what the case is regarding the letter closure which usually consists only of greetings and good wishes. Should this have been the case that such a letter opening got lost, then it might have been deliberately

1 So, for instance, W.L. Lane, Hebrews 9-13 (WBC 47B), Dallas 1998, 497. He based his argument on coherency, saying that " $\ldots$ this section transmits an essential message that can scarcely be separated from the concerns and themes of chaps. 1-12". Also C.J. Bjerkelund noticed that $\pi \propto p \propto \kappa \propto \lambda \tilde{\omega}$ is used in a distinct epistolary manner without separating these verses from the rest of Hebrews" (Parakalô: Form, Funktion und Sinn der parakalô-Sätze in den paulinischen Briefen, Oslo 1967, 31 f.).

2 Übelacker has shown that the personal note appended to the homily reflects the conventions of a postscript (W.G. Übelacker, Der Hebräerbrief als Appell. I. Untersuchungen zu exordium, narratio, und postscriptum (Hebr 1-2 und 13,22-25) [ConBNT 21], Stockholm 1989, 197-223). P. Ellingworth, in turn, reckons that "It is simpler, in the absence of manuscript evidence to the contrary, to consider vv. 22-25 as an integral part of Hebrews" (The Epistle to the Hebrews, Grand Rapids 1993, 732).

3 Ancient authors, such as Lucianus of Samosata in Syria clearly distinguished between the preface as head, the postscript and marginal notes, as well as the body $(\sigma \tilde{\omega} \mu \alpha)$ of a work. For examples, see E. Schweizer, Art. $\sigma \tilde{\omega} \mu \alpha$, TDNT 7,1140-1142. 
omitted at a very early stage in the history of the document in order to divert attention away from its real author and to include it alongside Paul's letters to the Romans and Corinthians as a Pauline letter in (some circles of) the early Christian tradition, such as is seen in $\mathfrak{P}^{46}$. Although this is theoretically and hypothetically not impossible, it is not the intention of this paper, though, to pursue such a possibility of a lost letter opening, but rather to explore the possible addition of vv. 22-25 at the end of the document as a potential later postscript.

Some have suggested that the whole of Hebrews 13 should be understood as a unit on its own which was added later after the completion of the book of Hebrews. ${ }^{4}$ This viewpoint has been rejected by scholarship with enough evidence to prove the integrity of Hebrews 13 in relation to the rest of Hebrews. ${ }^{5}$ Other scholars, however, took a more nuanced position in this regard and accepted the authenticity of the greatest part of Hebrews 13, but they doubted whether the last number of verses should be treated in the same manner. According to them, only the last verses are to be taken as a later addition. ${ }^{6}$ Even amongst these, there is no consensus about which verses it might be. Despite the fact that there are suggestions for Hebr 13,18-25 (Schunack) ${ }^{7}$ and Hebr 13,19-25 (Wrede), ${ }^{8}$ the majority of scholars in this group accept it to be Hebr 13,22-25. Even many scholars who do not accept vv. $22-25$ as a possible later addition also acknowledge an important structural and stylistic break in the text between v. 21 and v. $22 .{ }^{9}$ This in itself stands as evidence of the difference in nature

4 D. Trobisch, Die Entstehung der Paulusbriefsammlung (NTOA 10), Fribourg/Göttingen 1989, 117f; J. Thurén, Das Lobopfer der Hebräer. Studien zum Aufbau und Anliegen von Hebräer 13 (AAAbo.H 47/1), Åbo 1973, 51-53; H. Montefiore, A Commentary on the Epistle to the Hebrews (HNTC), New York 1964, 237-238; H. Strathmann, Der Brief an die Hebräer (NTD 9), Göttingen ${ }^{71963, ~ 152 ; ~ J . ~ H e ́ r i n g, ~ L ' e ́ p i ̂ t r e ~ a u x ~ H e ́ b r e u x ~(C N T[N] ~}$ 12), Neuchâtel 1954, 14.121.126; C. Spicq, L’Épître aux Hébreux II (EBib), Paris 1953, 415; J. Moffatt, Jesus Christ the Same, New York 1940, 224. According to Thurén, Hebrews 13 circulated independently and later formed the basis of the rest of the document (Lobopfer, 53-55.108.246-247).

5 Cf. G.H. Guthrie, The Structure of Hebrews [NT.S 73], Leiden 1994, 134; F.V. Filson, 'Yesterday': A Study of Hebrews in Light of Chapter 13 (SBT 2/4), Naperville 1967; A. Vanhoye, La question littéraire de Hébreux xiii. 1-6, NTS 23 (1976/77) 121-139; R.V. G. Tasker, The Integrity of the Epistle to the Hebrews, ET 47 (1935-36) 136-138; C.R. Williams, A Word-Study of Hebrews 13, JBL 30 (1911) 129-136.

6 This viewpoint is mainly supported by older literature in the field, e.g. W. Slot, De letterkundige vorm van den brief aan de Hebreeën, Groningen 1912, 52-55; A. Vanhoye, Situation du Christ. Hébreux 1-2, Paris 1969, 221; G.W. Buchanan, To the Hebrews (AncB 36), Garden City / New York 1972, 241.

7 G. Schunack, Der Hebräerbrief (ZBK.NT 14), Zürich 2002, 232.

8 W. Wrede, Das literarische Rätsel des Hebräerbriefs (FRLANT 8), Göttingen 1906.

9 Cf. W.L. Lane, Hebrews 9-13 (see n. 1), 497. K. Backhaus, in referring to Hebr 13,20-21, points to the recommendations of Quintillian for the writing of a closing passage where the key thoughts of the document are briefly summarized (Der Hebräerbrief [RNT], Regensburg 2009, 482). This might serve as further confirmation that the book of Hebrews was originally intended to end at v. 21. 
that is detected in vv. 22-25. Even scholars such as Bruce, a proponent for the unity of the whole document, calls Hebrews "a homily in written form, with some personal remarks added at the end", and legitimately asks the question: "But could a document of this length be appropriately spoken of as written "in few words?"'10

This paper intends then to revisit the hypothesis that the ending of Hebrews (vv. 22-25) might be a later addition (postscript), assuming that the original ending of Hebrews is actually to be found in vv. 18-21. Whether this assumed postscript was a later addition by the same author ${ }^{11}$ or by a later author remains, however, an open question.

\section{Observations from the oldest surviving manuscript: $\mathfrak{P}^{46}$}

It was already pointed out above that no surviving external evidence exists regarding the possible omission of Hebr 13,22-25. The oldest surviving manuscript of Hebrews, namely $\mathfrak{P}^{46}$, also contains the section under discussion. The collection of documents contained in $\mathfrak{P}^{46}$ consists of the following nine books in this order: Romans, Hebrews, 1 and 2 Corinthians, Ephesians, Galatians, Philippians, Colossians and 1 Thessalonians. There are missing pages at the beginning of Romans and towards the end at 1 Thessalonians. Proposals for the date of the manuscript range between the latter quarter of the $1^{\text {st }}$ century A.D. (Jaroš; ${ }^{12}$ Young Kyu Kim), ${ }^{13}$ somewhere between 150 and 250 A.D. (Griffin) ${ }^{14}$ the first half of the $3^{\text {rd }}$ century (Kenyon) ${ }^{15}$ and the second half of the $3^{\text {rd }}$ century (Sanders). ${ }^{16}$ However, the mainstream viewpoint accepts a date around 200 A.D.

At least two correctors were involved during the final stages of the manuscript. One can be identified with the scribe himself. The other is a later correc-

10 F.F. Bruce, The Epistle to the Hebrews, Grand Rapids 1985, 413.

11 So, for instance, B. Lindars, The Rhetorical Structure of Hebrews, NTS 35 (1989) $382-406$, here 385 .

12 "Ein besonderes Merkmal des Codex ist es, die Vorsilbe $\varepsilon \gamma$ - statt ع vor b, d, 1 (Röm 9,11; 11,5.7.26; 13,4; 16,13; Hebr 12,3.5; 13,7; 1 Kor 10,13) zu verwenden, was bereits auf eine frühe Entstehungszeit des Codex vor dem beginnenden 2. Jh. n. Chr. hinweist" (K. Jaroš, Das Neue Testament nach den ältesten griechischen Handschriften, Wien 2006, 1095). "Zusammenfassend kann gesagt werden, daß P 46 heute mit überzeugenden Argumenten ab dem letzten Viertel des 1. Jhs. datiert werden kann. Der bereits oben angeführte Hinweis auf den Schriftzug des Kopisten, die Schreibung der einzelnen Buchstaben und die Verwendung der $\varepsilon \gamma$-form vor b, d, und 1 schließen eine Entstehungszeit nach dem 1. Jh. geradezu aus!" (ebd., 1102).

13 Y.K. Kim, Palaeographical Dating of P 46 to the Later First Century, Bib. 69 (1988) 248-257.

14 B.W. Griffin, The Palaeographical Dating of P-46 (Unpublished paper, SBL New Orleans, Nov. 1996), 1-11.

15 F.G. Kenyon, The Chester Beatty Biblical Papyri III, London 1936, xiv-xv.

16 H.A. Sanders, A Third Century Papyrus Codex of the Epistles of Paul, Ann Arbor 1935. 
tor who also added the page numbers, reading marks and stichoi indicators at the end of each of the documents. In the case of Hebrews, this corrector wrote $\sum \operatorname{TIX} \Psi$, probably understanding it to be 700 lines. ${ }^{17}$

The question arises whether there might be any clues from the manuscript itself that could support the hypothesis of these verses as a later addition. Although very little could be deduced from the physical manuscript in this regard, a closer look at the ending of Hebrews in $\mathfrak{P}^{46}$ reveals at least the following interesting features:

a) Although it might be purely coincidental, it certainly is interesting that the section under discussion (vv. 22-25) starts on a new line in $\mathfrak{P}^{46}$. This, in combination with the ending of the previous line on ớr combination with further evidence - the suspicion that this peculiar ending could have been a later addition during the process of transmission.

b) The morphological use of $-\varepsilon 1$-instead of $-1-$ might have been a clue if it was only found in v. 22-25, but it is not only limited to these last few lines of Hebrews in $\mathfrak{P}^{46}$. It was actually a widespread phenomenon in the morphology of uncials anyway. The feature appears throughout the whole document, ${ }^{18}$ although inconsistently, and it cannot be used to support an argument in favour of a later addition.

c) The position of the book of Hebrews by the compiler of $\mathfrak{P}^{46}$ between Paul's letters to the Romans and 1 Corinthians remains an interesting hermeneutical key in understanding the compiler's position regarding Hebrews. He most likely intended it to be understood as belonging to the Pauline corpus. In addition to this, the earliest reference to Hebrews, i.e. by Clement of Rome in his letter to the Corinthians, raises possible interesting connections between Hebrews, Rome and Corinth. The connection with Timothy and the author's intended visit in Hebr 13,22-25 as well as the placement of Hebrews between Romans and Corinthians by the compiler of $\mathfrak{P}^{46}$, might be indicators of some assumed Pauline connection with Hebrews that was probably based on this postscript. 19

d) It is also interesting that $\mathfrak{S}^{46}$ already added the headings of the books in this compilation, amongst them the heading to the book of Hebrews. If this ad-

17 The actual number is more probably between 938 lines (Jaroš, Handschriften [see n. 12], 1095 ) and 873 lines (according to my own count, GJS).

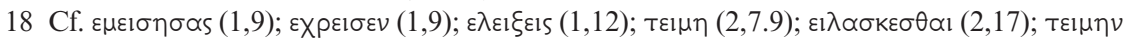

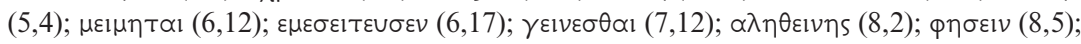

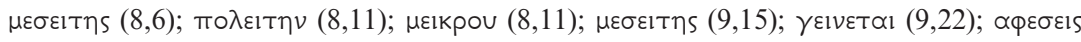

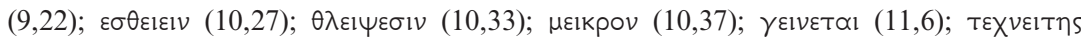

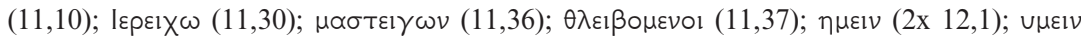

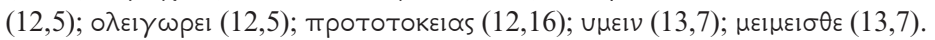

19 Cf. H.-F. Weiß: "Mit V. 23 folgt eine weitere persönliche Bemerkung, mit der Autor sich selbst ganz offensichtlich bewußt in die Kontinuität der Mission des Apostels Paulus einordnet." "Umso deutlicher zu erkennen ist jedoch die vom Autor beabsichtigte Beziehung zu den Briefen des Paulus" (Der Brief an die Hebräer [KEK 13], Göttingen 1991, 763). 
dition of the heading could have been included at such an early stage of the textual history of Hebrews, then so similarly could a later postscript also be included during the early stages of Hebrews' textual evolution. Examples of similar cases might serve as supporting evidence, although this will be left towards the end of this particular investigation.

All these observations lead to questions regarding the nature and status of the postscript. This needs attention, but again only after the internal evidence has been scrutinized as well.

\section{A closer look at Hebr 13,22-25 as a possible postcript}

The closure at Hebr 13,21 with ợn่v seems to be a structurally logical and functionally concluding point of this document. Although there are a few supporting cases in the NT epistolary literature where this is the last word in the document, ${ }^{20}$ there are more cases where ớn $v$ concludes just a particular thought, after which further information then follows. ${ }^{21}$ The most interesting cases which show close similarities with Hebr 13,21-22 are those that are directly followed after $\propto$ ’ $\mu \eta \dot{v} \nu$ by $\pi \propto \rho \propto \kappa \propto \lambda \tilde{\omega}$ in Rom 11,36-12,1 (i.e. at the concluding section of Rom 9-11) and in Eph 3,21-4,1 (i.e. at the concluding section of Eph 1-3). Two

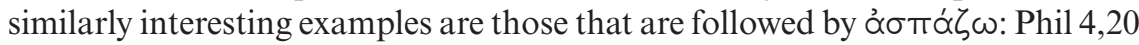

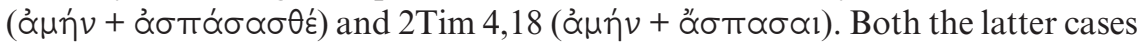
are particularly interesting as they occur towards the end of the letters. There is thus enough evidence to argue that this practice was not unknown and that Hebr 13,22-25 does not necessarily need to be a later addition.

However, the case of Hebr 13,22-25 does not strictly fit into either of the two categories of $\alpha^{\prime} \mu \eta \dot{v} \nu+\pi \propto \rho \alpha \kappa \propto \lambda \tilde{\omega}$ or $\alpha^{\prime} \mu \eta \dot{\nu} \nu+\alpha^{\prime} \sigma \pi \alpha \dot{\zeta} \omega$. In the first category, the cases occur at major breaks in the overall macro structure of the letters

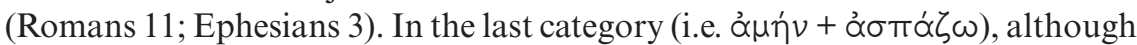
the cases also occur towards the end of the letters similar to Hebrews, the emphasis is mainly on the greetings and concluding grace-formula. Neither of these two cases includes also elements such as the emphasized encouragement of Hebr 13,22 and additional information such as the release of Timothy in Hebr 13,23. In this sense then, the case of Hebr 13,22-25 belongs to a category of its own and does not fit similar existing cases in the NT epistolary literature. It rather seems to be a combination between the $\pi \propto \rho \alpha \kappa \alpha \lambda \tilde{\omega}$ and $\alpha \dot{\sigma} \pi \alpha \dot{\zeta} \zeta \omega$ categories.

At this point, it would be appropriate to investigate the different elements, or statements, to be found in the closing section of Hebr 13,22-25:

20 Cf. Rom 16,27; Gal 6,18; 2Pet 3,18; Jud 25.

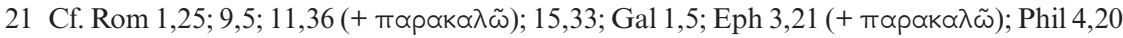

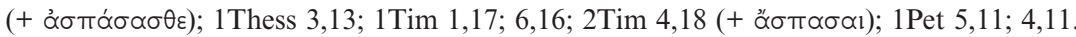
Weiß, amongst others, therefore see no difficulties to include Hebr 13,22-25 with the rest of the book and says that this "unmittelbare stilistische Übergang ... erklärt sich aus dem traditionellen urchristlichen Briefschema” (Hebräer [see n. 19], 760). 


\subsection{An appeal to attend to "the word of exhortation" 22 П $\alpha \rho \alpha \kappa \propto \lambda \tilde{\omega}^{23}$

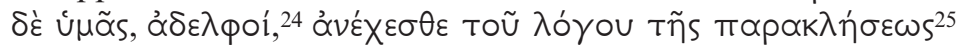 (Hebr 13,22a).}

Apart from here in Hebrews (13,19 and 13,22), the petition element occurs at several places in the NT, e.g. by Paul as well as in 1Pet 2,11 and 5,1.26 The extensive study of Bjerkelund ${ }^{27}$ on $\pi \propto p \propto k \propto \lambda \varepsilon \dot{\varepsilon} \omega$ has shown, firstly, that its use by Paul as part of a "stereotyped formula" 28 in the closing sections of his letters ${ }^{29}$ does not contain the prepositional phrase ( $\delta$ ı $\alpha$ plus the genitive) typically found with this formula, and secondly, that it always addresses the relation between the congregation and specific individuals or groups within the congregation. ${ }^{30}$ Scholars have argued, quite rightly so, that $\pi \propto p \propto \kappa \propto \lambda \tilde{\omega}$ is also to be found in the previous section (i.e. 13,19, and even earlier in 3,13) where it is used in the same sense. ${ }^{31}$ They assume on this basis that its use in Hebr 13,22 could thus not be part of a later addition, ${ }^{32}$ but that it belongs to the original version of the document. However, in such a later added postscript it would deliberately and intentionally pick up the nature and theme of the document, ${ }^{33}$ thus linking the postscript with the rest. ${ }^{34}$ The reinforcement of a previously given com-

22 E.g., Lane, Hebrews 9-13 [see n. 1], 568: "The descriptive phrase 'word of exhortation' is appropriate to a homily in written form".

23 Cf. also Hebr 3,13; 10,25; and 13,19.

24 Regarding the letter closings in Paul, J.A.D. Weima, Neglected Endings: The Significance of the Pauline Letter Closings (JSNT.S 101), Sheffield 1994, 145 pointed out that "The exhortations are ... more frequently (introduced) by the vocative ơ $\delta \varepsilon \lambda \phi \circ$ ' (Rom. 16.17; 2 Cor. 13.11; Phil. 4.8; 1 Thess. 5.25; Phlm. 20; see 1 Cor. 16.15)".

25 Cf. also Rom 15,4; 2 Cor 1,3; 8,4; Acts 4,36; 13,15; Hebr 6,18 and 12,5. According to Harrison, the term "... is used in Hebrews 13:22 as a description of the entire epistle" (sic! GJS) (E.F. Harrison, The Apostolic Church, Grand Rapids 1985, 134).

26 Cf. T.Y. Mullins, Formulas in New Testament Epistles, JBL 91 (1972) 380-390, here 390.

27 Bjerkelund, Parakalô (see n. 1), 128-129.

28 Weima, Neglected Endings (see n. 24), 145.

29 Cf. Rom 16,17; 1Cor 16,15. See also Phil 4,2 and 1Thess 5,14.

30 Cf. also Weima, Neglected Endings (see n. 24), 145.

31 So, for instance, Ellingworth, Hebrews (see n. 2), 732. He argues that "The frequent passages of paraenesis make it also appropriate; and тарók $\lambda \eta \sigma 1 s$ applies better to Hebrews as a whole than to these concluding, directly epistolary verses".

32 Weiß, without a sign of doubt, simply assumes then that "... die folgende Bitte bzw. Aufforderung (läßt) erneut das Besondere des ganzen Hebr hervortreten ... als Trost- und Mahnschreiben" (Hebräer [see n. 19], 761).

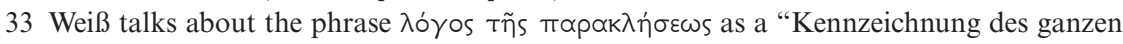
Schreibens" (Hebräer [see n. 19], 761).

34 Lane's (Hebrews 9-13 [see n. 1], 567) argument could thus be used to argue the exact opposite of the position that he takes: "The postscript is attached to the homily by a linking device that reveals the literary signature of the writer: corresponding to $\delta \dot{\varepsilon} \pi \alpha \rho \alpha \kappa \alpha \lambda \tilde{\omega}$, 'and I urge,' in v 19 is the exhortation $\pi \propto p \propto \kappa \propto \lambda \omega \tilde{\omega} \delta$ ', 'and I urge,' in v 22" (L. Dussaut, Synopse structurelle de l’Épître aux Hébreux, Paris 1981, 134-135). 
mand $^{35}$ and the fact that a subscription typically repeats the important points in a document have been argued convincingly in independent studies ${ }^{36}$ so that the similarity in vocabulary and the frequency in occurrence do not necessarily testify to this section being part of the initial document.

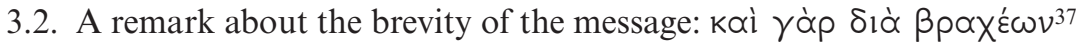

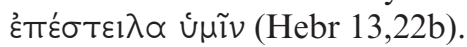

The term $\beta \rho \alpha \times \varepsilon \dot{\varepsilon} \omega v$ is used only seven times in the NT: three times in LukeActs, ${ }^{38}$ once in John's Gospel ${ }^{39}$ and three times in Hebrews. The other two occurrences in Hebrews, apart from 13,22, are to be found in the quotation from Ps 8 (Hebr 2,7) with its commentary (Hebr 2,9). The question should be asked whether $\delta i \alpha \beta \beta \propto \chi \dot{\varepsilon} \omega \nu$ refers here to the whole of Hebrews, or perhaps only to the closing section itself ${ }^{40}$ Most scholars assume that the reference applies to the whole document. ${ }^{41}$ It is firstly motivated on the basis of grammatical and syntactical arguments. One reason for such a viewpoint is on the

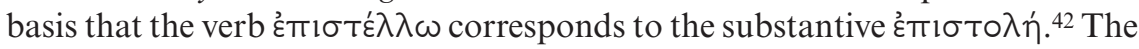

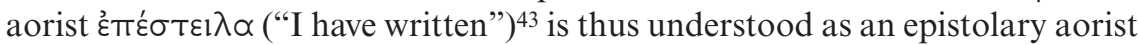
which refers in this sense not "to some distant past event, but to the act of sending the letter, which for the reader is a past event". ${ }^{44}$ Based on the structure of the sentence in v. 22, it is furthermore assumed that $\delta ı \alpha \beta \rho \alpha x \dot{\varepsilon} \omega v$ qualifies the

35 Cf. Weima, Neglected Endings (see n. 24) 53-54: "A postscript can also reinforce a command previously given in a letter". P. Oxy. 1481 and P. Wisc. 74 are supporting examples in this regard.

36 So also E.R. Richards, The Secretary in the Letters of Paul [WUNT II/42], Tübingen 1991, 82: "It is noteworthy that the subscription typically repeats the important points".

37 Also to be found in the quotation from Ps 8,5-7 in Hebr 2,7.

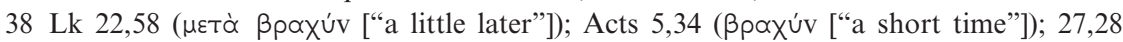
( $\beta p \alpha x u ́ v$ ["a little further"]).

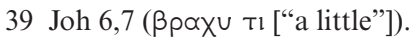

40 A. Vanhoye, took it as a reference applying only to these last verses (La Structure littéraire de l'épître aux Hébreux, Paris 1976, 221-222).

41 Cf., for instance, Weiß, Hebräer [see n. 19], 762. Schunack says: "Die Bitte samt knapper Erläuterung in V. 22 nimmt metakommunikativ Bezug auf den nunmehr abgeschlossenen homiletischen Traktat, wie dies prospektiv schon in 5,11 erfolgte" (Hebräerbrief [see n. 7], 232. 238). See also G.J. Bahr, The Subscriptions in the Pauline Letters, JBL 87 (1968) 27-41, here 36; Bruce, Hebrews (see n. 10), 413. Furthermore Ellingworth: "The reference to brevity ( $\delta ı \alpha$ ’ $\beta p \alpha \chi \dot{\varepsilon} \omega v$, see below) is a literary convention which may quite well cover a writing as long as Hebrews: Josephus (Ant. 20.266) uses $\beta p \alpha \chi \varepsilon$ c $\alpha$ to refer to writing at least twice as long; it would have taken about an hour to read Hebrews aloud" (Hebrews [see n. 2], 732).

42 Bruce, Hebrews (see n. 10), 413.

43 Could it also be translated: "I am writing"? (Cf. 1Cor 1:1 and translation of epistolary aorist there).

44 So H.W. Attridge - although he admits that "the choice of the verb is somewhat unusual" (The Epistle to the Hebrews (Hermeneia), Philadelphia 1989, 408). 


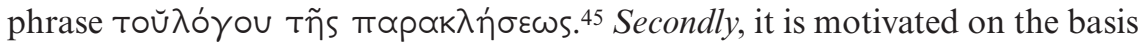
of a stylistic, literary or rhetorical argument. In this sense, the remark is understood as intended irony to "put up" with the homily and that the author literally means that his work has been brief ( $\delta 1 \dot{\alpha} \beta p \propto x \varepsilon \dot{\varepsilon} \omega v)$, i.e. that he wrote "through short (things, words"). ${ }^{46}$ Lane follows the same line of argumentation, implying that this reference to brevity, " ... is simply a polite literary convention, with parallels in Jewish ${ }^{47}$ and early Christian documents". ${ }^{48}$ But the

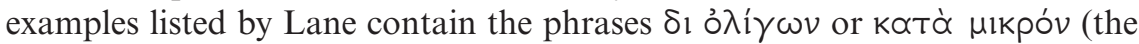
latter in the case of Barnabas - which one might argue was the author's initial intention when he started his letter). Hebrews, to the contrary, uses Siò $\beta p \propto \chi \dot{\varepsilon} \omega \nu .{ }^{49}$ Although Weiß is thinking in the same direction, he does not want to see the phrase - in reference to the whole book - only in the sense of "einer bestimmten rhetorischen Gepflogenheit", but also as the author's own understanding of the character and extent of his exposition ("Rede"). ${ }^{50}$

Other scholars took a different position by distinguishing either between the "word of exhortation" (Hebr 1-12) and the "few words" (to be Hebr 13,1-19), ${ }^{51}$ or simply between the rest of the book and Hebrews 13 - which, in their opinion, could be considered as "a covering letter to accompany the treatise". ${ }^{52}$ Bruce denies this viewpoint, whilst arguing that "it is the length of the exhortation, not its content, that our author thinks the readers might begin to find wearisome". .53

45 Lane, Hebrews 9-13 (see n. 1), 568.

46 Attridge, Hebrews (see n. 44), 408. He argues that we have here the "Use of the 'ironic, rhetorical appeal' 'a $v \varepsilon \chi_{\chi} \varepsilon \sigma \theta \varepsilon$ to 'put up with' his work" and that this is a common meaning of the verb, cf. Mt 17,17; Eph 4,2; Col 3,13.

47 E.g. 2Macc 2,31-32; 6,17.

48 W.L. Lane lists the following examples (Hebrews 9-13 [see n. 1], 569): 1Pet 5,12: "I have written briefly" [ $\delta i$ ó $\lambda i ́ \gamma \omega \nu$ है $\gamma \rho \propto \psi \alpha$ ]; Ignatius, Rom. 8,2; "I beg you by these few lines"

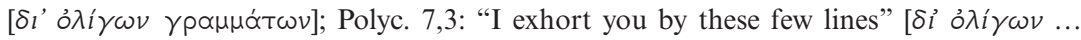

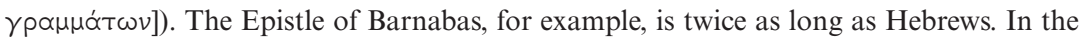

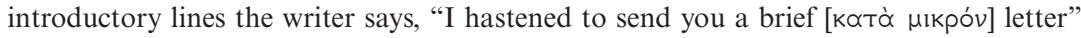
(Barn 1,5).

49 Ellingworth states, however: " $\Delta ı \dot{\alpha} \beta p a x \varepsilon \dot{\varepsilon} \omega v$, 'in a few words, briefly,' is a somewhat more literary synonym for $\delta l^{\prime}$ o $\lambda \hat{i} \gamma \omega \nu$ in a similar context in 1 Pet. 5:12, where $\mathrm{p}^{72}$ indeed reads

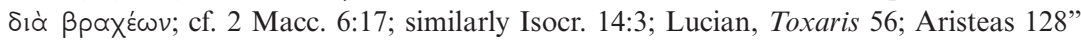
(Hebrews [see n. 2], 732-733).

50 Weiß, Hebräer [see n. 19], 762.

51 G.A. Simcox, Heb. xiii; 2 Tim. iv, ET 46 (1934-35), 562-567; Vanhoye, Structure

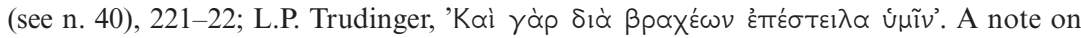

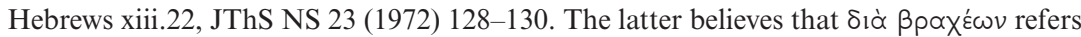
only to Hebr 13.

52 R. Anderson, The Hebrews Epistle in the Light of the Types, London 1911, 12.

53 Bruce, Hebrews (see n. 10), 414. 
A postscript was often typified by its brevity 54 and this remark

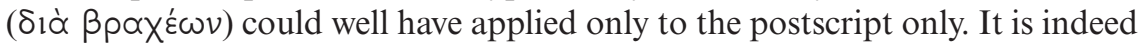
possible that either the author or a later writer had the intention to strengthen the paraenetic nature of the document by adding in a brief note the new information about the release of Timothy in order to encourage the readers. One could argue in favour of either position based on the use of $\dot{\varepsilon} \pi \varepsilon \dot{\varepsilon} \sigma \tau \varepsilon \lambda \propto \alpha$. On the one hand, scholarship provided sufficient evidence that the author might have intended sending the whole document as a brief message. (It is interesting to note how translations followed this interpretation and translated here "letter")..$^{55}$ On the other hand, however, a case could also be made for the postscript being sent as a "brief message" on its own, in addition to the message of the book itself. ${ }^{56}$ Furthermore, the possibility that, should the author have used an alternative term such as $\dot{\varepsilon} \gamma \rho \alpha \dot{\psi} \psi \propto$ instead of $\dot{\varepsilon} \pi \dot{\varepsilon} \sigma \tau \varepsilon ı \lambda \propto$ and that the choice of terminology might assist in the choice of either position here, is also not of any help. Its absence or presence could again apply to either the author writing the whole document briefly, or to the author of the postscript who wrote that part briefly. In the light of all of the above, the possibility certainly seems to be kept open that the reference about the brief message might apply to the postscript as such.

54 Cf. Weima, Neglected Endings (see n. 24), 53: "postcriptive remarks are typically brief and often consist of one of the formal conventions belonging to the letter closing, such as a greeting or a health wish". So, similarly, Richards, Secretary (see n. 36), 82: "The subscription, however, could vary considerably, ranging from an elaborate and thorough summary of the body to only a very brief sketch". Several examples are listed in this regard by Richards (ibidem).

55 Hebr 13,22 is so translated in the New International Version ("short letter"), King James Version ("I have written a letter"), Good News Version ("this letter I have written") and Het Boek ("deze vermanende brief ter harte te nemen; zo lang is deze niet"). This is also implied in the Gute Nachricht ("ich habe mich ja so kurz wie möglich gefasst"). More correct are the Luther Bibel 1912 and 1984 and Einheitsübersetzung ("ich habe euch kurz geschrieben"), the New Revised Standard Version, English Standard Version and New American Version ("I have written to you briefly"), as well as the American Standard Version ("I have written unto you in few words"). The New Century Version translates "this message I have written" and the New Living Translation "I have written in this brief exhortation".

56 It might also be important to ponder the question about how exactly one should translate

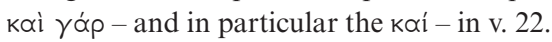




\subsection{The announcement of the release of Timothy and an intended visit by

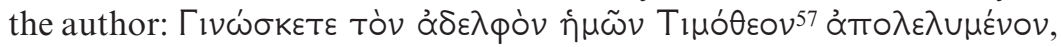

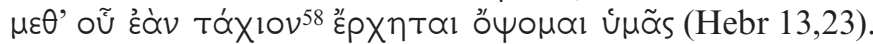

This brief reference about the release of Timothy comes almost as a sudden surprise towards the end of the document. ${ }^{59}$ Timothy always appears in the prescript of the letters where he is mentioned, ${ }^{60}$ except in Romans $(16,21)$ where he is listed in the postscript. He acted as Paul's convoy and spoke on Paul's behalf to the Corinthians (1Cor 4,$17 ; 16,10-11) .{ }^{61}$ No information survived regarding the imprisonment of Timothy and suggestions in this regard abound in scholarship. The most popular opinion seems to be Rome during Paul's imprisonment there, based on the information of 2 Timothy $(4,9.11$. 13. 21). There is at least one indication in the prescript of Philemon 1 that Timothy shared an imprisonment with Paul. ${ }^{62}$ However, there is uncertainty whether this reference here in Hebr 13,23 refers to release from imprisonment only. ${ }^{3}$ This uncertainty

57 Occurs only 8 times in the NT. Apart from here in Hebr 13,23, also in the headings of 1/2Tim; 1Thess 3,2; 1Cor 4,17; Phil 2,19; Acts 17,15 and 19,22.

58 According to Ellingworth, there "are indeed points of contact between this verse and

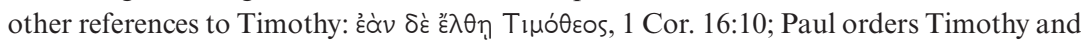
Silas to follow him ஸ́s тóx $1 \sigma \tau \propto$ to Athens, Acts 17:15; Paul hopes to send Timothy to Philippi $\tau \propto \chi \varepsilon \dot{\varepsilon} \omega s$, Phil. 2:19. Such coincidences are quite insufficient to support the view that the present verse is (part of) a pastiche of other NT references to Timothy, and the likely reference to Timothy's (otherwise unknown) imprisonment would tell against this theory" (Hebrews [see n. 2], 735).

59 Schunack quite rightly asks: "So ist die Frage, welchen Sinn dieser Hinweis auf Timotheus hier hat" (Hebräerbrief [see n. 7], 232).

60 Cf. 1Thess 1,1; 2Cor 1,1; Phil 1,1; Phil 1; cf. also 2Thess 1,1; Col 1,1.

61 Ellingworth summarises the relation between Paul and Timothy as follows: "The NT Timothy was Paul's companion from the time of their first meeting at Lystra (Acts 16:1-3; cf. 20:4). He was entrusted by Paul with missions in Macedonia (Acts 17:14, with Silas; cf. 18:5; 19:22, with Erastus; 1 Thes. 3:2, cf. 3:6), to Corinth (1 Cor. 4:17; cf. 16:10; with Silas, 2 Cor. 1:19), and perhaps to Philippi (Phil. 2:19). Paul associates Timothy with himself in the opening of Philippians, Colossians, 1 and 2 Thessalonians, and Philemon; whether this implies joint authorship is, however, doubtful. Timothy is described as Paul's 'brother' (see above), his 'fellow-worker' (Rom. 16:21), his 'true child in faith' (1 Tim. 1:2), and his 'beloved child' (2 Tim. 1:2). This close and (apart from the present verse) apparently exclusive relationship with Paul may have been a factor in the attribution of Hebrews to Paul" (Hebrews [see n. 2], 734).

62 Attridge, Hebrews (see n. 44), 409.

63 Similarly C.-P. März: “... die Übers.(etzung) 'Abreise' fügt sich besser zum Reisegedanken als die meist aufgenommene Wiedergabe als 'Haftentlassung”" (Hebräerbrief [NEB 16],

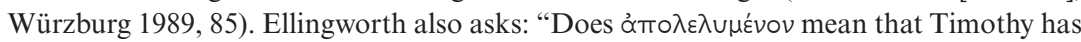
been 'released,' by implication from prison ...?" He further comments: "In the NT, apart from the present text, ớro $\lambda$ ú $\omega$ is used only in the Gospels and Acts. Here the context gives little help in defining the meaning" and that "There is no other NT reference to Timothy's imprisonment. On balance, with a majority of commentators (including Attridge), the meaning 'release' is probably to be preferred, but 'departure' is not impossible" (Hebrews 
also leaves open the possibility that the reference could have a similar intention as that found in 1 Thess 3,6-10 where Timothy is being sent back (i.e. "released from service" in the sense of departure) by the Thessalonians to Paul. In 1Cor 16,11 Paul urges the Corinthians to send Timothy back to him. ${ }^{64} \mathrm{~A}$ dispatching formula regarding Timothy is also to be found in Phil 2,19-23. ${ }^{65}$ Reference was already made to the intended but implicit Pauline connections in this verse. More important, however, is that the author does not here take the last step to explicitly use the name of Paul for himself.66

Research indicated already that in a postscript, "the writer (sometimes) may give some new information that has come to light immediately following

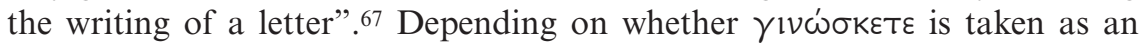
indicative or an imperative, the author either wanted to remind his readers of something, or to give them new information. The latter seems, however, to be preferred. ${ }^{68}$ This statement assumes here that there is an existing relationship between Timothy and the author, as well as between Timothy and the readers. ${ }^{69}$ Timothy might be closer to the author of Hebrews than to the readers on two grounds: (a) the author knows about his release before the readers do, and (b) Timothy could join him to travel with the author to the readers. ${ }^{70}$ The release of Timothy (from prison or service) certainly was understood to be important information and welcome news to the audience. ${ }^{71}$

[see n. 2], 733-734). Schunack raised the same uncertainty: "Das Part. Perfekt könnte zwar auch besagen, dass er aus Kerkerhaft freigelassen worden ist, doch wäre derartiges kaum nur so knapp erwähnt worden" (Hebräerbrief [see n. 7], 239).

64 Cf. M.M. Mitchell, New Testament Envoys in the Context of Greco-Roman Diplomatic and Epistolary Conventions: The Example of Timothy and Titus, JBL 111 (1992) 641-662, here 650 .

65 Mitchell, ibid., 652.

66 Weiß, Hebräer [see n. 19], 763. So also Schunack: "Er bleibt anonym und nimmt für seine Person keine andere 'amtliche' Autorität in Anspruch ..." (Hebräerbrief [see n. 7], 238).

67 Cf. Weima, Neglected Endings (see n. 24), 53. Some examples listed by Weima include P. Mich. 490, P. Tebt. 41, P. Oxy. 937, P. Oxy. 1063 and Cicero's postscripts.

68 Ellingworth, Hebrews (see n. 2), 733.

69 Schunack, Hebräerbrief (see n. 7), 238. According to Ellingworth three things are clear from the remark about Timothy's release here: "First, there is no reason to suppose that the author's visit to the receptors was in any way dependent on Timothy's coming ..."; "Second, although there is no contradiction between this verse and v. 19, the hope of an early visit to the readers, expressed in v. 19, now seems to have strengthened into expectation that such a visit will soon take place. Third, the statement suggests that the author himself is not confined in prison" (Ellingworth, Hebrews [see n. 2], 733).

70 Bruce, Hebrews (see n. 10), 413.

71 So also Lane, Hebrews 9-13 (see n. 1), 569. 


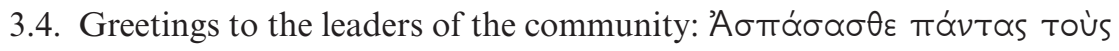

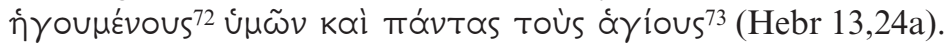

Greetings in letter closures are indications of a certain relationship that existed between authors and their audiences. These greetings were characterized by personal information and a bond of friendship or familiarity. ${ }^{74}$ They are typical of the epistolary literature in the NT and the greetings in Hebr 13,24 show similarities with such letter endings. Attention has already been drawn, for instance, to the similarities between Phil 4,19-23 and Hebr 13,20ff.:

"Auf den Segenswunsch und die Doxologie von Phil 4,19f folgt in Phil 4,21f die Mitteilung

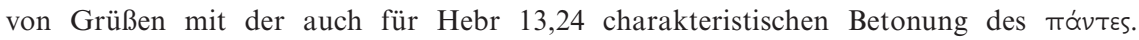
Gerade diese 'Besonderheit' von V. 24 könnte sich somit durchaus daraus erklären, daß der Autor des Hebr in dieser Hinsicht ein bestimmtes traditionelles Muster der Paulusbriefe übernimmt. ${ }^{75}$

Although Schunack has also drawn attention to the fact that the greetings in v.24 follow the "urchristlichen, paulinisch geprägten Briefschema", he is cautious and reluctant to deduce that a "Pauline colour" could be identified here and that Hebr 13,24 might have been structured on the pattern of Phil 4,19-23. ${ }^{76}$ A word of caution is certainly in place here, but a "Pauline colour" cannot be denied. Nonetheless, despite such similarities, this particular greeting in Hebr 13,24 is unique in the sense that it distinguishes between the leaders and the community at large. ${ }^{77}$

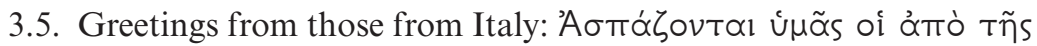

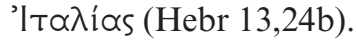

There is nothing strange to the place of a greeting such as this within the structure of a letter closure. However, what is striking here in Hebr 13,24, is that - in the absence of a letter opening - this is the only place in Hebrews where con-

72 The term is only found once more in the NT, namely in Acts 15,22 .

73 Cf. also Rom 16,15; 1Cor 16,1; 2 Cor 8,4; 9,1; Eph 1,4. 15; Col 1,4. 22; Phlm 5; Acts 9,32. 41 and 1 Joh 2,20.

74 "It was essentially one of those gestures which has little intellectual content but which has emotional expression as its main purpose" (T.Y. Mullins, Greeting as a New Testament Form, JBL 87 [1968] 418-426, here 419).

75 Weiß, Hebräer [see n. 19], 764.

76 Schunack, Hebräerbrief (see n. 7), 239. Backhaus is of a similar opinion and cautions against the idea of a pseudepigraphic imitation of a Pauline letter - but particularly with regard to Hebr 13,20-21. He states: "Unser Abschnitt weist nach Struktur und Kontext deutliche Entsprechungen zum konventionellen Briefformular auf, wie es sowohl in paulinischen als auch in anderen urchristlichen Schreiben belegt ist. Auf die pseudepigraphisch fingierende Nachahmung eines Paulus-Briefes last dies keineswegs schließen" (Hebräerbrief [see n. 9], 483).

77 Ellingworth, Hebrews (see n. 2), 736. 
crete evidence is found about any particular geographical place. ${ }^{78}$ It has been argued convincingly in the literature that it might imply that the document was written from somewhere in Italy, or that it was written from somewhere outside Italy with the implication that the Italians living there are also sending their greetings. Should it be assumed that Hebr 13,22-25 was a later addition, then this piece of information might only be intended to reflect the context of the author of this postscript. This could then still well be the original author who shortly after the completion of the document added this note when he shares the latest news about the release of Timothy. Alternatively, should this be a remark from the hand of a later editor, such as the compiler of $\mathfrak{P}^{46}$ for instance, then he deliberately added this information as part of the intention and purpose of his postscript in order to make a link with apostolic (particularly Pauline) authority.

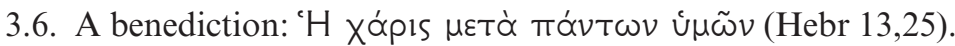

The typical letter closing of Hellenistic letters consisted initially of two (but later three) formulae, namely a wish for good health of the recipient and a word of farewell. But the Pauline and other primitive Christian letters were "less bound to the closing conventions of the Hellenistic letters ...: neither the health wish nor the Greek word of farewell is found in Pauline letter closings". ${ }^{79}$ Rather a benediction or doxology appears in its place. The Xópıs-phrase is fairly consistent in the genuine Pauline letters (including its occurrence in Ephesians). It reads different, however, in Colossians, the Pastoral Letters and in Hebrews - where the latter is identical with the occurrence in Tit 3,15. Again there seems to be an interesting difference here. The Pauline and other NT epistolary literature have a Christological expansion in this formula - which lacks in both Tit 3,15 and here in Hebr 13,25.80

The absence of $\alpha \mu \eta \dot{v} v$ at the end of the document, testified by $\mathfrak{P}^{46}$ and $\mathrm{a}^{*}$ (also omitted in the reconstruction of the Greek text of Nestle/Aland ${ }^{27}$ ), probably reflects the original version. Although its absence at the very end of the document, in the light of its presence in 13,21 , seems to be odd, it is certainly not unique and cannot be used as independent evidence in support of a later addition.

78 “Dieser Deutung folgen überwiegend die 'Subskriptionen' (Unterschriften) in der handschriftlichen Überlieferung des Hebr" (Schunack, Hebräerbrief [see n. 7], 240).

79 W.G. Doty, Letters in Primitive Christianity, Cambridge 51988, 39-40.

80 "Er ist nicht wie in paulinischen und anderen neutestamentlichen Briefen christologisch erweitert und näher bestimmt, sondern beschränkt sich darauf, allen die Gnade Gottes zuzusprechen ..." (Schunack, Hebräerbrief [see n. 7], 240). 


\section{What is the nature of the assumed addition?}

But what is the nature of Hebr 13,22-25? Is it a letter on its own, or a formal letter ending by the same author, a later postscript, a kind of colophon by a later scribe, or an editorial hinge by a later editor or compiler of a collection such as $\mathfrak{P}^{46}$ ? Each will now be briefly considered in the light of the discussion above.

\subsection{An "embedded letter" in the text?}

Embedded letters in ancient literature were not uncommon. ${ }^{81}$ However, this piece (v. 22-25) lacks a letter opening of its own and occurs at the very end of the document instead of somewhere in the body of the document - such as is the case, for instance, with Acts 15,23-29. The ending of Hebrews was thus most probably not intended as an embedded letter on its own.

\subsection{A "letter closure"?}

The preferred option in current scholarship is to consider Hebr 13,22-25 as a kind of "letter ending", usually written by the same author. Weiß, for instance, considers 13,18-25 to be a "Briefschluß" 82 and calls the section 13,22-25 a "Persönliches Begleitwort" 83 or "briefliches Begleitschreiben" 84 and the whole of Hebrews a "brieflich zugesandte Rede". ${ }^{85}$ Gräßer 86 (Hebr 13,22-25) and Schunack $^{87}$ (Hebr 13,18-25) take a more nuanced position, labeling the last verses a "brieflicher Schluss" and Schunack calls particularly v. 22-25 "ein brieflicher Nachtrag" 88 - a position followed by Koester ${ }^{89}$ and Attridge ${ }^{90}$ who call Hebr 13,22-25 an "epistolary postscript". Bjerkelund, in turn, confirmed

81 Cf. P.A. Rosenmeyer, Ancient epistolary fictions. The letter in Greek literature, Cambridge 2001, on embedded letters in, for example, Euripides (pp. 61-97) and in Greek novels (pp. 133-168).

82 Although Backhaus deals with the unit 13,1-25 as a "briefliche Schluss", he talks of 13,20-21 as a "Briefschluß" that takes the form of a "Segenswusch" (Hebräerbrief [see n. 9], 482).

83 Weiß, Hebräer [see n. 19], 10, 748-766.

84 Weiß, Hebräer (see n. 19), 761.

85 Weiß, Hebräer (see n. 19), 761.

86 E. Gräßer, An die Hebräer. III. Hebr 10,19-13,25 (EKK XVII/3) Neukirchen 1997, 409.

87 Schunack, Hebräerbrief (see n. 7), 232. Schunack argues further: "Schließlich ist es Kennzeichen brieflicher Kommunikation, dass der Verf.(asser) erstmals ausdrücklich in eigener Person spricht, V. 19.22f., und eine aktuelle Beziehung zur Gemeinde anspricht”.

88 Schunack, Hebräerbrief (see n. 7), 232.

89 C.R. Koester, Hebrews, Rhetoric and the Future of Humanity, CBQ 64 (2002) 103-123, here 106.

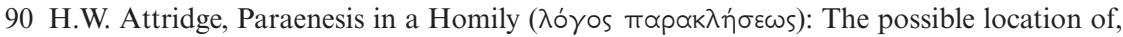
and socialization in, the 'Epistle to the Hebrews', Semeia 50 (1990) 211-226, here 217. 
the position of a letter closure on the basis of his study of $\pi \propto p \propto k \alpha \lambda \tilde{\omega} \cdot{ }^{91}$ This perception also found its way implicitly in some of the Bible translations. It is exactly on the basis of these verses being perceived as a "letter closure" that this book became known as "The Letter" to the Hebrews - despite the fact that Hebrews is not a letter.

\subsection{A "postscript"?}

Technically, a distinction should be made between a formal kind of "letter ending" and a "postscript". ${ }^{92}$ The assumption in scholarship seems to be that it would have been more likely that the same author added Hebr 13,22-25 as such a "letter ending" - most often understood to be during the time of the writing of Hebrews. A "postscript", on the other hand, was added later. It could still have been by the same author, or by a later hand. Weima defines the postscript in epistolary writings as follows:

"A postscript consists of final remarks that, for one reason for another, have been omitted from the formal letter closing, and so are appended to the end. A postscript is by definition not a normative letter-closing convention, but a feature that arises out of the necessity to include some final information that was not earlier included." 93

Examples of postscripts abound and several papyri, for instance, contained postscripts. ${ }^{94}$ BGU IV, 1207 (received 5 Nov 28 B.C.E) contains a fairly long postscript. In P.Mich. VIII, 490, 491 ( $2^{\text {nd }}$ cent C.E., i.e. around the time of the compilation of $\mathfrak{P}^{46}$ ) a postscript is found in a second hand: "Know that I have been assigned to Misenum, for I found out later" (i.e., after the letter was

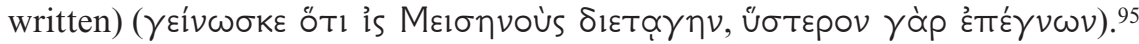
A New Testament example might be identified in 1Cor 16,24, which, although being a unique postscript to Paul's letter closings, "it is typical of ancient Hellenistic and Jewish letters that frequently contain a brief remark following the

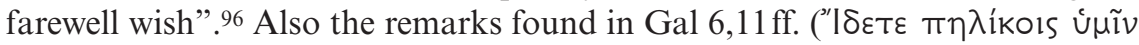

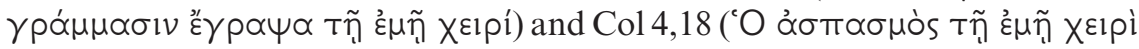

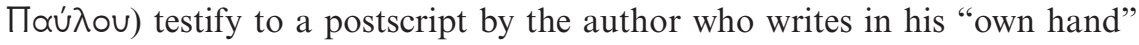
these last lines. ${ }^{97}$

91 Bjerkelund, Parakalô (see n. 1), 31.

92 It seems as if at least two types of postscripts, namely "summaries" and "additional material", can be identified in a Greco-Roman letter when they are categorized by content (Richards, Secretary [see n. 36], 81).

93 Weima, Neglected Endings (see n. 24), 52.

94 J.L. White, Light from Ancient Letters, Philadelphia 1986, 237.

95 White, ibid., 162.

96 Weima, Neglected Endings (see n. 24), 152.

97 Ellingworth reminded, however, that "It is possible though unprovable that they were added in the author's own hand" (Hebrews [see n. 2], 732). See also B. Lindars, The Rhetorical Structure of Hebrews, NTS 35 (1989) 382-406, here 385. 
Turning again to Hebrews, some scholars have taken a more nuanced position regarding the ending of Hebrews. Several factors are acknowledged. It is clear that Hebr 13,22-25 consists of both additional information as well as personal greetings. Bruce, therefore, defines it then as a "postscript" where a "few personal notes are appended". ${ }^{98}$ It is also clear that there is a break between Hebr 13,21 and 13,22. Guthrie ${ }^{99}$ and Schunack ${ }^{100}$, therefore, understand the last few verses to be added later after the finalization of the document, but still before the document was sent to its readers. Backhaus holds a similar opinion to that of a postscript and understands this section to be a "Begleitnotiz". ${ }^{101}$

\subsection{A "colophon" by a scribe?}

The possibility exists that Hebr 13,22-25 could also be an addition in the form of a colophon by an amenuensis or a scribe. No external evidence exists, however, in this regard to prove this point and such an assumption would be highly speculative.

\subsection{An "editorial hinge" by a compiler?}

Alternatively, the ending of Hebrews might have been a kind of "editorial hinge" that was added by a later compiler during the first stages of the compilation of epistolary literature. ${ }^{102}$ It would have been possible that a compiler, such as that of $\mathfrak{P}^{46}$, might have written these verses on a Pauline mold and added them in order to give apostolic authority to the book of Hebrews and to include it alongside the Pauline letters.

98 F.F. Bruce, The Structure and Argument of Hebrews, SWJT 28 (1985) 6-12, here 12.

99 "The benediction of Heb. 13:20-21 probably was the ending to the original sermon, and the closing, found in verses $22-25$, an addendum added when the manuscript was sent by courier" (Guthrie, Structure [see n. 5], 134). This view is in line with that of Lane, Hebrews 9-13 (see n. 1), 495-507.

100 "Die sachliche wie auch stilistische Zäsur legt deshalb nahe, V. 22-25 als ein kurzes Begleitschreiben mit brieflichem Schluss anzusehen ..." (Schunack, Hebräerbrief [see n. 7], 238).

101 "Diese dürfte freilich die des Auctor ad Hebraeos selbst sein, der dem Schreiben, das er diktiert hat, eine persönliche Begleitnotiz anfügt. Der Brauch, dass der diktierende Verfasser, oft mit eigener ... Hand ... ein Postskript anfügte, war im Briefverkehr verbreitet und bot gewissermaßen einen letzten, persönlichen Handschlag" (Backhaus, Hebräerbrief [see n. 9], 488).

102 Cf. M. Dibelius / H. Greeven who refer to a similar case regarding the Letter of James (James [Hermeneia], Philadelphia 1975, 1-2). 


\section{Conclusion}

Schunack appropriately summarized the problem regarding Hebrews under discussion here:

"Er beginnt als homiletischer Traktat und ist insgesamt als solcher strukturiert, endet aber als Brief. Das damit aufgeworfene Problem last sich freilich nicht auf den eindeutig brieflichen Nachtrag V. 22-25 beschränken, da schon in V. 19 die Situation brieflicher Kommunikation im Blick ist und auch in V. 18 und V. 20f. Formen und Motive eines urchristlich traditionellen Briefschlusses aufgenommen werden. Zur Irritation trägt auch bei, dass sich gerade im brieflichen Schluss V. 18-25 deutliche Anklänge an Motive und Wendungen anderer neutestamentlicher Briefe finden. ${ }^{103}$

The question about the nature of Hebr 13,22-25 is in essence a question about the relation between the rest of the book ("Rede' des Hebr") and this ending taken then by most scholars to be a typical letter closure ("briefliche Gestalt"). ${ }^{104}$ One position is to consider Hebr 13,22-25 as an integral part of the original document, most likely originating at the same time when the document was written. This position is currently accepted to be the case by mainline scholarship in Hebrews. Another position, however, would be to consider Hebr 13,22-25 as a later addition - being that by the same author, or by someone else. This position, although always present in the history of investigation, does not seem to be a popular one. It was the intention of this paper to revisit this alternative again and to assess some of the available evidence. The following arguments, based mainly on the internal evidence ${ }^{105}$ of the text, could possibly be tabled in favour of v. $22-25$ as a later addition:

a) Although the exact beginning of the controversial ending of Hebrews remains open for discussion (v. 18, v. 19 or v. 22), the logical concluding point to the document seems more likely to be at the ớn $\mu^{\prime}$ of v. 21. ${ }^{106}$ Furthermore, in terms of possible external evidence, it seems very coincidental that the section following from v. 22, starts on a new line in $\mathfrak{P}^{46}$.

b) Hebr 13,22-25 does not strictly fit into the two categories of $\alpha \mu \eta \dot{v} v+$ $\pi \propto p \propto \kappa \propto \lambda \tilde{\omega}$ or $\propto \dot{\alpha} \mu \eta \dot{v} \nu+\alpha^{\prime} \sigma \pi \propto \dot{\zeta} \zeta \omega$ in relation to the other epistolary literature of the NT and belongs to a category of its own. It seems to be a combination between the $\pi \propto p \propto \kappa \propto \lambda \tilde{\omega}$ and $\alpha$ $\sigma \pi \alpha ́ \zeta \omega$ categories.

103 Schunack, Hebräerbrief (see n. 7), 233. See also the examples listed by Schunack in this regard.

104 Cf. Weiß: "Die Kennzeichnung der literarischen Gestalt des Hebr als einer 'brieflich übermittelten Rede' entspricht somit am besten seiner literarischen Eigenart” (Hebräer [see n. 19], 762).

105 See B.M. Metzger on this (The Text of New Testament. Its Transmission, Corruption and Restoration, Oxford 21979, 17-21).

106 So also Gräßer: "Mit dem 'Amen' in 13,21c ist der Hebr zu Ende”. He notes further: "Daß ả $\mu \eta \dot{v} v$ nur 'das Ende der offiziellen Ansprache' markiere und 'diese von den meher persönlichen Mitteilungen und Grüßen' abgrenze, 'die der Vf. Als Postscriptum hinzugefügt hat' (Übelacker, 198f), kann nicht überzeugen” (Hebräer, 409). 
c) The remark about the brevity of the writing ( $\delta ı \alpha$ $\beta \rho \alpha \chi \dot{\varepsilon} \omega \nu)$ could well have applied only to the postscript. It might have been the intention of the author or a later writer to strengthen the paraenetic nature of the document by adding a brief note with the new information about the release of Timothy in order to encourage the readers.

d) The note about Timothy's release and the author's intended visit shows a deliberate, but implicit, Pauline connection. ${ }^{107}$ It seems as if the author of this postscript intentionally wanted to give the document apostolic authority and to provide a "Pauline colour" to the document. This possible imitation of a Pauline letter closure can also be noticed in the similarity between the greeting of Hebr 13,24 and the pattern of Phil 4,19-23. An intended Pauline connection is further enhanced by the Italian greeting.

e) The absence of a Christological expansion in the grace formula is striking. It shows an alternative but possibly standard formula (based on Tit 3,15) that is different from the custom in the Pauline literature - which could serve as supporting evidence against Pauline authorship.

Thus, there seems to be little doubt that Hebr 13,22-25 is a postscript that was added later and which reminds of a kind of letter closure. The addition complies with the conventions and peculiarities of a postscript (at the end of the document; is typically brief in nature; contains a blessing at the end; shares information that became available after the completion of the document; reinforces a command previously given). Supporting evidence also exists of similar postscripts in other ancient literature which confirms this practice.

Some questions remain, however. Firstly, there is the question about the stage, or time delay, at which the postscript was added. The postscript could have been added during the time of the author ${ }^{108}$ and prior to the letter's first original dispatch with the intention of sharing a short note about the news of Timothy's release. ${ }^{109}$ Alternatively, it might have been added at a later stage in the textual history of Hebrews - most probably during a phase where a compiler or collector wanted to present the document with Pauline authority. This leads to the question about the nature of the connection with the Pauline tradi-

107 "Was folgt, ist ein pseudo-paulinischer Briefschluß, der dem anonym abgefaßten Schreiben apostolische Würde verleihen soll” (E. Gräßer, Hebräer III [see n. 85], 409). Backhaus, however, is of another opinion: "Dass die Schlusszeilen dem Hebr nachträglich in pseudepigraphischer Absicht einen paulinischen Anstrich geben sollen, ist unwahrscheinlich" (Hebräerbrief [see n. 9], 488).

108 "The author's identity was already known to the intended audience, and it would appear that he already had some rapport with them (13:22-25)" (Koester, Hebrews [see n. 88], 109).

109 Contrary to this, it has to be agreed with E. Gräßer: "Zumeist wird angenommen, daß es der Hebr-Autor selbst war, der diesen Schluß seinem Schreiben als 'briefliches Begleitwort' beigegeben habe. Aber es ist kaum vorstellbar, daß unser dem Paulinismus völlig fernstehender Autor seiner 'für Gottesdienst bestimmten Ansprache' zuletzt den Anschein eines Paulusbriefes gegeben haben sollte. Nein!” (Hebräer III [see n. 85], 409). 
tion (similarities with Paul's $\pi \propto p \propto \kappa \propto \lambda \varepsilon \dot{\varepsilon} \omega$ closings; listing between the Pauline letters in $\mathfrak{P}^{46}$; release of Timothy and the intended visit by the author). The absence of any authoritative indications is probably a sign of a forgery that intended the document to be written by Paul. ${ }^{110}$

110 Similar cases are to be found, for instance, in the letters of Plato with most of them probably being forgeries in this regard (cf. W.G. Doty, The Epistle in Late Hellenism and and Early Christianity: Developments, Influences, and Literary Form [PhD diss.; Drew University, 1966], 53; Richards, Secretary [see n. 36], 86). Schunack also raised this issue: “... nötigt V. 23, wenn es sich um eine fiktive Angabe handelt, zusammen mit einem 'paulinischen Kolorit' sogar dazu, V. 22-25 insgesamt als Fiktion eines apostolischen Briefschlusses aufzufassen?" (Hebräerbrief [see n. 7], 238). Schunack, however, rejects this viewpoint: "Die Annahme hingegen, V. 22-25 insgesamt sei die Fiktion eines Paulusbriefs zu geben und ihm dadurch kanonische Anerkennung zu verschaffen, führt erst recht in Aporien" (p. 239). 